\title{
Environmental and Institutional Impacts of Tidal River Management: A Case Study on Pakhimara Tidal Basin in Southwestern Bangladesh
}

\author{
Md. Tareq Bin Salam*, Atika Ibnat Amin', Tonami Afroz ${ }^{1}$ and Md. Mahedi Al Masud \\ ${ }^{1}$ Soil, Water and Environment Discipline, Khulna University, Khulna-9208, Bangladesh; ${ }^{2}$ Department \\ of Social Services, Ministry of Social Welfare, Government of Bangladesh, Bangladesh \\ *Corresponding author: tareqss@swe.ku.ac.bd
}

\begin{abstract}
People in southwestern Bangladesh have been facing the waterlogging problem and protesting on the impacts for the nature for a long time. In the 1960s, the government introduced polders, embankments and cross dams to overcome the destructive scenario. Due to the failure of government initiatives, the local people of the coastal area cut into the polder so that the sediment deposited within the beel known as Tidal River Management (TRM). Then, TRM was applied several times in different catchments. The study was carried out from December 2018 to November 2019 to assess the positive and negative environmental and institutional impacts of TRM on Pakhimara beel in Tala Upazila (Sub-district), Satkhira District, by using the Sustainability Index of Tidal River Management (SITRM) framework. Sustainability Indices of TRM were designed to provide information on social, environmental and institutional gains. The environmental and institutional impacts were assessed by conducting household survey and Key Informant Interviews (KIIs). Agricultural impacts on crop, poultry, fisheries and vegetation, were also analyzed by comparing GIS map and agricultural production data (before and after TRM). This study investigated that Pakhimara beel was freed from waterlogging during the with-TRM event by 3,200 ha and the reduction of waterlogging increased agricultural land by 1,500 ha in 2018 , compared to 2014 . This study argued that only $54 \%$ of marginal farmers received crop compensation whereas $85 \%$ of crop production decreased due to TRM. For promoting sustainable TRM in the studied area, compensation should be guaranteed for all impacted parties, especially marginal farmers and the creation of employment opportunities, and settlement should be ensured.
\end{abstract}

Keywords: agricultural impact; employment impact; sustainability index; waterlogging

Cite this as: Salam, M. T. B., Amin, A. I., Afroz, T., \& Al Masud, M. M. (2021). Environmental and Institutional Impacts of Tidal River Management: a Case Study on Pakhimara Tidal Basin in Southwestern Bangladesh. Caraka Tani: Journal of Sustainable Agriculture, 36(2), 295-307. doi: http://dx.doi.org/10.20961/carakatani.v36i2.50486

\section{INTRODUCTION}

The southwestern region of Bangladesh is the area most affected by climate in the country because of its geographic location. Due to climate change, this area remains as one of the most vulnerable areas that cover mainly of Khulna, Jashore, Bagerhat and Satkhira districts (Gain et al., 2017; Roy et al., 2017). Before the polderization, the local people experience flooding twice a day (Nicholls et al., 2008). The government started the coastal embankment project in the coastal area to control tidal flooding and salinity intrusion for agricultural development (Dewan et al., 2015). The polders were considered to be effective in the early years of operation because they reduced floods and created stability in agriculture. However, tidal sediment could not be raised in the beel due to polderization, instead it fell into the river. Thus in a few

\footnotetext{
* Received for publication April 20, 2021

Accepted after corrections June 7, 2021
} 
years, the river could be no longer drained of rainwater, causing waterlogging (Islam, 2014). Sedimentation in the tidal rivers is the main reason for waterlogging (Sarwar and Khan, 2007). In this region people, agriculture, biodiversity and the environment received the worst impacts of this project. Many areas remained underwater for more than nine months in a year (Jakarya et al., 2016). People used their indigenous knowledge to save their crops from waterlogging (Brammer, 2014). To prevent the water congestion, local people initiated a temporarily solutions to cut away the embankments to allow the tidal flow in the flood plain. This process is called Tidal River Management (TRM) (Kibria, 2011; Gain et al., 2017; van Staveren et al., 2017).

TRM involves taking full advantage of the natural tidal flow in the rivers. In high tide, water enters into the beel and is deposited in its bottom, instead of the river, and this reduces waterlogging, improves the navigability of the river and creates stability in agriculture (Gain et al., 2017). TRM brings blessing for local dwellers by creating positive impacts on land development and food security (Masud et al., 2018; Mutahara et al., 2018; Gain et al., 2019b). However, TRM is a big challenge for the local people in implementing tidal basin because land owners want to sacrifice their land for implementing the project and compensation is not monotonous for all owners. Therefore, there is a significant conflict among stakeholders for implementing TRM (Dewan et al., 2015). Small farmers are being impacted badly whereas big land owners sometimes get more compensation. The study is going to reveal these problems and sort them in the implemented TRM tidal basin.

TRM has a potential influence on extending agriculture because of decreasing waterlogging (Khadim et al., 2013; Paul et al., 2013; Cornwall, 2018; Mutahara et al., 2018; Gain et al., 2019a). Due to waterlogging and intrusion of saline water in the agricultural land, soil salinity is increasing sharply in the southwestern part of the country (Salam et al., 2019) and almost $30 \%$ of the cultivable land has already been contaminated with the salinity (Khatun et al., 2019). Hossain and Salam (2019) mentioned that the physicochemical properties of the soil in the southwestern part of the country are hampered by various degree of salinity. Masud and Azad (2018) and Masud et al. (2018) stated that TRM might enhance the crop yield and bring economic benefits by declining waterlogging and water congestion. However, financial benefits have not been determined due to the TRM. TRM also plays a role in the improvement of livelihoods (Seijger et al., 2019). If government take necessary actions for economic improvement of the stakeholders, TRM can be the best option for removing water congestion and improving the local living pattern. Shampa and Pramanik (2012); Seijger et al. (2019); Adnan et al. (2020) and Masud et al. (2020) studied the impacts of TRM on various components, like waterlogging, flood alleviation, livelihood pattern and agricultural sustainability in the catchment areas. In most of the cases, they found the positive outcomes in implementing TRM but the novelty of this research is that we study the tidal basin area where the TRM is being implemented.

TRM has been implemented in 12 out of 35 beels in the Ganges-Brahmaputra delta. According to Masud and Azad (2018), TRM potentially increases crop yields and thus improves the socio-economic condition of that area. Pakhimara is now the only active TRM project in Bangladesh. The Pakhimara TRM beel is located in Jalalpur Union of Tala Upazila of Satkhira District. The Kobadak River is a full tidal river. For about 150 years, the Kobadak River had no connection with the Padma stream. Without the implementation of TRM, the existence of this river cannot be sustained (Shampa and Pramanik, 2012). The government adopted a projection of 2011 under the name of "Project phase 1 to remove the Kobadak River dam" to protect the residents of the Kobadak River and basin. One of the parts of project was the establishment of TRM in the Pakhimara beel. TRM project was launched in July 7, 2015 , with the cooperation of the administration. The implementing authority of the project was the Bangladesh Water Development Board (BWDB). In the meantime, the TRM project had been in place for 3 years and 10 months until December 2018. During the visit on April 7, 2018, the Deputy Commissioner of Satkhira informed the public that the TRM program would be continued until 2021 (Uttaran et al., 2013). Thus, TRM raised controversial thoughts for the local stakeholders. Due to the long time, the project already gave the negative effects to the local dwellers in the implementing areas. This research allowed us to identify the TRM approach on 
the Pakhimara beel to gather knowledge of the way and the degree this technique influence people's life.

\section{MATERIALS AND METHOD}

\section{Selection of the study areas}

Four villages were selected from three different unions in Pakhimara tidal basin for analyzing with and without-TRM conditions (Figure 1). The study areas are located at a $22^{\circ} 35^{\prime} 0^{\prime \prime}$ to $22^{\circ} 50^{\prime} 0^{\prime \prime} \mathrm{N}$ and $89^{\circ} 5^{\prime} 0^{\prime \prime}$ to $89^{\circ} 20^{\prime} 0^{\prime \prime}$ E. The average temperature of the study areas was $28{ }^{\circ} \mathrm{C}$. April and May were the hottest months and the temperature varied from $35{ }^{\circ} \mathrm{C}$ to $42{ }^{\circ} \mathrm{C}$. On the contrary, January was the coolest month of the year and the temperature ranged from $10{ }^{\circ} \mathrm{C}$ to $12{ }^{\circ} \mathrm{C}$. Mostly, the study area received highest rainfall in July and August successively, and the average rainfall was 220 mm (SRDI, 2007). The study was conducted from December 2018 to November 2019. Therefore, the tenure of the study was one year. A total of 27 beels were situated in the Ganges-Brahmaputra catchment area. In most of the cases, farmers tended to use the beels for their agriculture production, like crops and fisheries. Four out of 27 of them had already been introduced with TRM and the remaining 23 were non-TRM beels. However, beels play an important role of local farmer's livelihood.

\section{Methods of data collection}

The analysis was completed by using both primary and secondary data. Primary data were collected through household surveys and KII (Key Informant Interviews). The secondary data were gathered from several documents of government, journals, websites, books and non-governmental organization named Uttaran.

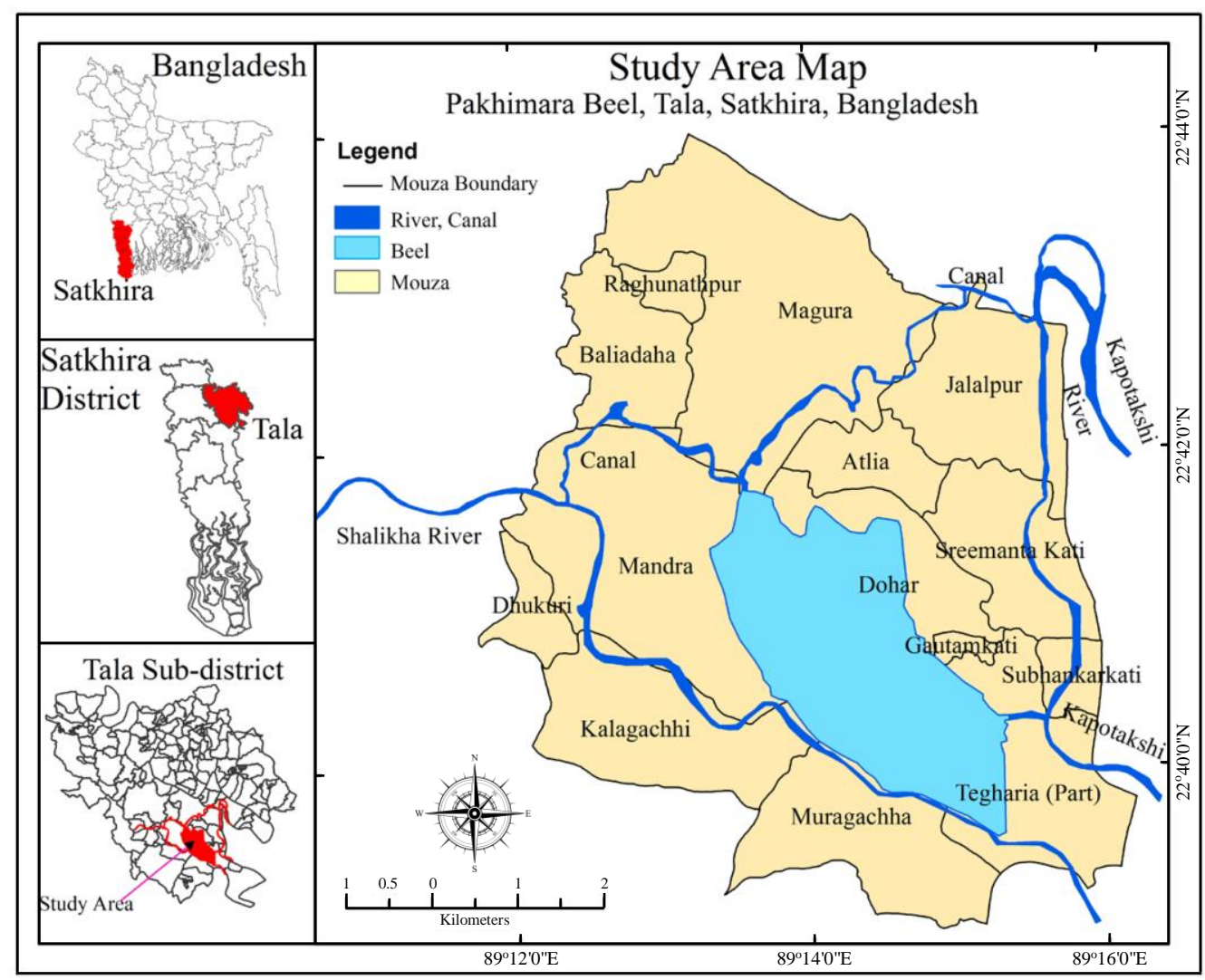

Figure 1. Map of the study area (Hussain et al., 2018)

\section{Sustainability index of tidal river management (SITRM)}

These days, the term sustainability seems to cover many aspects. Masud et al. (2018) used different sustainability indices for detecting potential SITRM components and indicators based on the information of social, environmental and economic benefits. This index comprised six components and 21 indicators. In this study, we used five components and 13 indicators of SITRM to assess the environmental and institutional impacts of TRM that are presented in Table 1. 
Table 1. Sustainability indices of TRM

\begin{tabular}{ll}
\hline \multicolumn{1}{c}{ Components } & \multicolumn{1}{c}{ Indicators } \\
\hline Sedimentation & Waterlogging \\
\hline Environment & Crop production \\
& Vegetation with settlement \\
& Employment \\
& Terrestrial biodiversity \\
& Migration \\
& Water quality (drinking water problem) \\
\hline Human health & Health impact (diarrhea disease) \\
& Sanitation \\
\hline Institution (community participation) & Awareness and coordination \\
& Compensation \\
\hline Institution (governance) & Rotation of TRM in the beels \\
& Water governance \\
\hline
\end{tabular}

Source: Masud et al. (2018)

Table 2. Sample size determination for household survey at Pakhimara beel

\begin{tabular}{ccccc}
\hline Village & Total household & Farmer household & Target household & Sample size \\
\hline Baliya & 723 & 719 & 431 & 44 \\
Dohar & 783 & 548 & 329 & 34 \\
Mandra & 730 & 584 & 350 & 36 \\
Tegharia & 141 & 141 & 85 & 10 \\
\hline
\end{tabular}

Total population $(\mathrm{N})=1,195$

Total sample size $(\mathrm{n})=124$

\section{Assessing the environmental and institutional impacts of TRM}

Sample size determination

This study used household surveys to collect data relating to crop production, livestock, as well as trees, employment, migration and water quality issues from different villages in the Pakhimara tidal basin for the two time periods of 2012-14 (without TRM) and 2016-18 (with TRM). This study identified that $60 \%$ of respondents were small-scale farmers (who had <1 acre of cultivable land), $34 \%$ repondents were middle farmers (who had 1-5 acre of cultivable land) and 6\% respondents were big farmers (who had $>5$ acres of cultivable land) at Pakhimara beel. Farmers having less than 1 acre of cultivable land at Pakhimara beel were the target population of this study. The sample size (n) was determined by using the following equation, as proposed by Kothari (2004).

$$
\mathrm{n}=\frac{\mathrm{z}^{2} \times \mathrm{p} \times \mathrm{q} \times \mathrm{n}}{\mathrm{e}^{2} \times(\mathrm{N}-1)+\mathrm{Z}^{2} \cdot \mathrm{p} \cdot \mathrm{q}}
$$

Where,

$\mathrm{Z}=$ the value of standard variate at a given confidence level (for 95\% confidence level, $\mathrm{z}$ is 1.96)

$\mathrm{P}=$ sample proportion (for $10 \%$ household, $\mathrm{p}$ is 0.1 )

$\mathrm{Q}=1-\mathrm{p}=0.9$

$\mathrm{N}=$ population size of the village

$\mathrm{E}=$ sampling error (within 5\% true value, $\mathrm{e}$ is 0.05 )

A stratified random sampling method was used for household surveys. The sample size of this survey was 124 that covered a maximum of 44 households from Baliya and a minimum of 10 households from Tegharia Village (Table 2).

Method for assessing the waterlogging and vegetation with settlement

Waterlogging and vegetation with settlement have been analyzed using remote sensing technology. The images of 2014 represented 'without TRM' phase and 2018 represented 'with TRM' phase. For representing premonsoon, monsoon and post-monsoon periods three images were captured during April, August 
and December, respectively, for 2014 and 2018. All satellite images were classified into three classes, including water body, agricultural land and vegetation with settlement. The acquisition of the images was performed in 22 April, 12 August, 18 December 2014, and 1 April, 7 August, 13 December 2018. The methods for assessing the riverbank erosion, awareness and coordination, rotation of TRM beel, and water governance issues in the Pakhimara tidal basin were discussed by involving 30 KIIs in expert judgement. Members of beel committee, surveyors, teachers, social service officers and businessman who have adequate knowledge about the Pakhimara beel were selected for KIIs.

\section{RESULTS AND DISCUSSION}

\section{Assessment of the environmental and institutional impacts of TRM}

Changes of terrestrial biodiversity (livestock and trees)

This research involved hen, duck, goose for bird animals and cow and goat for the fourlegged animal, as the available livestock; blackberry (Rubus plicatus), jackfruit (Artocarpus heterophyllus), mango (Mangifera indica), sofeda (Manilkara zapota), date (Phoenix dactylifera), coconut (Cocos nucifera) and betel nut (Areca catechu) for fruit trees; and neem (Azadirachta indica), mahogany (Swietenia macrophylla) and sissoo (Dalbergia sissoo) for timber trees, which were available in two time periods withoutTRM (2012-14) and with-TRM (2016-18) in the basin. Table 3 presents that hen and cow were most abundant in these periods. The total number of birds, animals and four-legged animals were decreased by $58 \%$ and $60 \%$, respectively, at with-TRM phase, as compared to the withoutTRM phase.

The changes in livestock in the tidal basin occurred due to the reduction of grazing land because beel created a lack of fodder for livestock. Figure 2 shows that betel nut (Areca catechu) and mahogany (Swietenia macrophylla) were the most abundant trees in the basin. The total number of fruit trees and timber trees decreased by $27 \%$ and $28 \%$, respectively, at with-TRM phase as compared to without-TRM phase in the basin. During TRM implementation, the peripheral dam to protect the village in the Pakhimara beel was not built high and strong enough. During the full moon, the height of the tide increased and the dam and its overflowing area were flooded that allowed saline water to intrude in the homestead area and reduced the production of fruit and timber trees. Individually, only the number of betel nut (Areca catechu) increased by eight times at withTRM phase, as compared to without-TRM phase.

Table 3. Changes in livestock (bird animals and four-legged animals) in the tidal basin

\begin{tabular}{lccccccccc}
\hline \multirow{2}{*}{ TRM phase } & \multicolumn{3}{c}{ Bird animals } & \multicolumn{2}{c}{ Change } & \multicolumn{2}{c}{$\begin{array}{c}\text { Four-legged } \\
\text { animals }\end{array}$} & \multicolumn{2}{c}{ Change } \\
\cline { 2 - 10 } & Hen & Duck & Goose & Total & Percentage & Cow & Goat & Total & Percentage \\
\hline $\begin{array}{l}\text { Without TRM } \\
(2012-14)\end{array}$ & 1,226 & 1,098 & 112 & 2,436 & & 537 & 395 & 952 & \\
$\begin{array}{l}\text { With TRM } \\
(2016-18)\end{array}$ & 614 & 397 & 13 & 1,024 & $-58 \%$ & 233 & 150 & 383 & $-60 \%$ \\
\hline
\end{tabular}

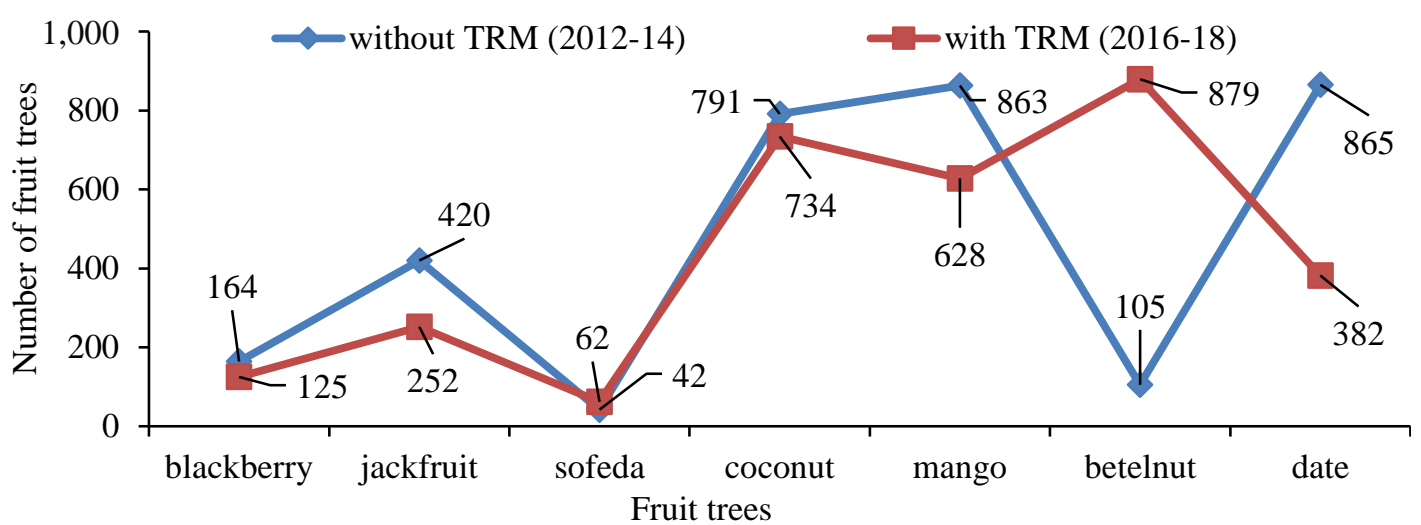




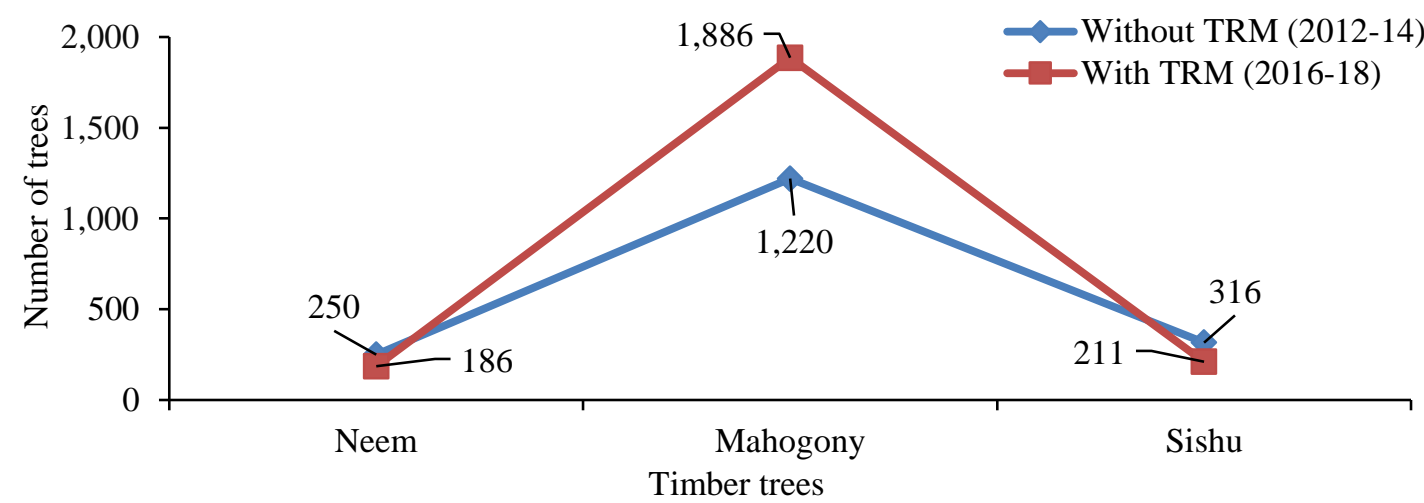

b.

Figure 2. Changes in fruit trees (a) and timber trees (b) in the tidal basin

\section{Rate of migration}

Migration is usual in this tidal basin as it is a running TRM project in Bangladesh. Unemployed people migrated to cities in search of temporary work. When the beel was filled and waterlogged was removed, people began to move back to their land. The people of this area temporarily migrated
(15\%) and most of them moved to urban areas $(80 \%)$ to seek for new occupation. They permanently migrated to other areas during 2012-14 (0.8\%) and 2016-18 (16\%) (Figure 3). Temporary migration of the people increased by $65 \%$ at with-TRM (2016-18) and permanent migration increased by $14 \%$ at with-TRM (2016-18).

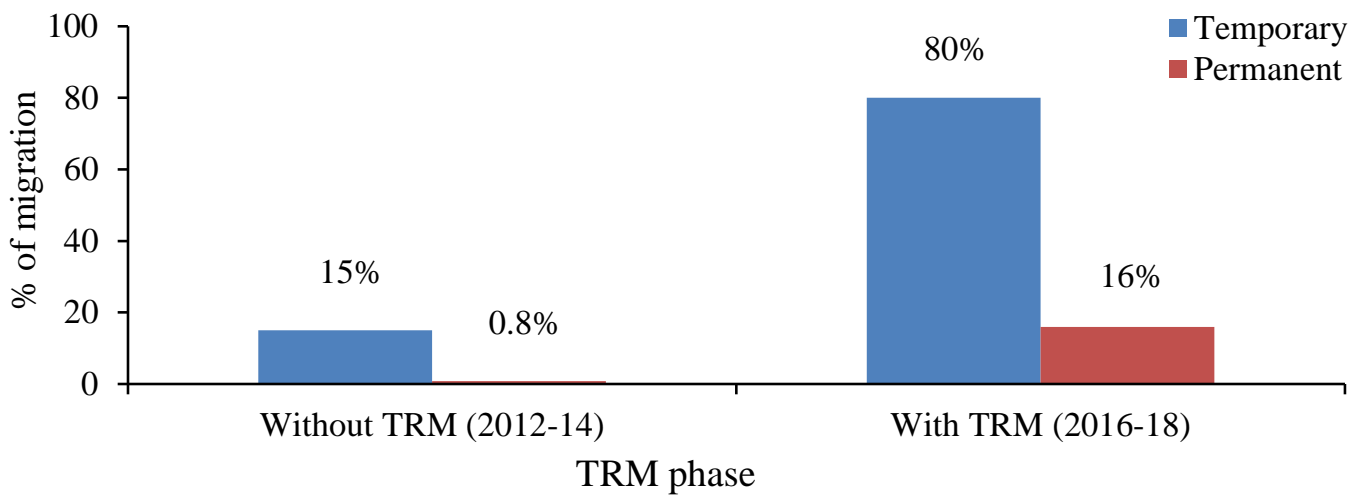

Figure 3. Changes in migration in the tidal basin

\section{Changes in agricultural production}

This study assessed the changes in the yields for five major agricultural production, including boro, vegetables, prawn, shrimp and white fish, in four villages. During TRM, the yield of boro decreased by $98 \%$ (Table 4). Before the implementation of TRM project, fish or paddy and vegetables were cultivated at the same time in the beel. However, during the TRM operation, vegetables were not cultivated but catch fisheries (natural wetlands) were available. The average production of fisheries (shrimp and white fish) dropped by $85 \%$ at with-TRM event (Table 4).

Table 4. Changes in the agricultural production in the tidal basin

\begin{tabular}{lccccc}
\hline TRM phase & \multicolumn{5}{c}{ Agricultural production in total land (ha) } \\
& Boro & Vegetable & Prawn & Shrimp & White fish \\
\hline $\begin{array}{l}\text { Without TRM } \\
\begin{array}{l}(2012-14) \\
\text { With TRM }\end{array}\end{array}$ & 150 & 120 & 122 & 436 & 89 \\
$(2016-18)$ & 4 & 33 & 13 & 58 & 12 \\
\hline Change & $-98 \%$ & $-72 \%$ & $-89 \%$ & $-87 \%$ & $-83 \%$ \\
\hline
\end{tabular}


Figure 4 presents the occurrence of drinking water problem due to waterlogged condition. Before the TRM implementation, the whole area was gone underwater and the people were forced to use unsafe drinking water due to the absence of pure drinking water. During the TRM phase, the problems reduced slightly.
Figure 4 also demonstrates that $74 \%$ of households living in the basin area faced problems related to drinking water at without-TRM (201214) phase and $69 \%$ of households were challenged with water problem at with-TRM (2016-18) phase. The problems improved by 5\% with-TRM event when compared to the without-TRM event.

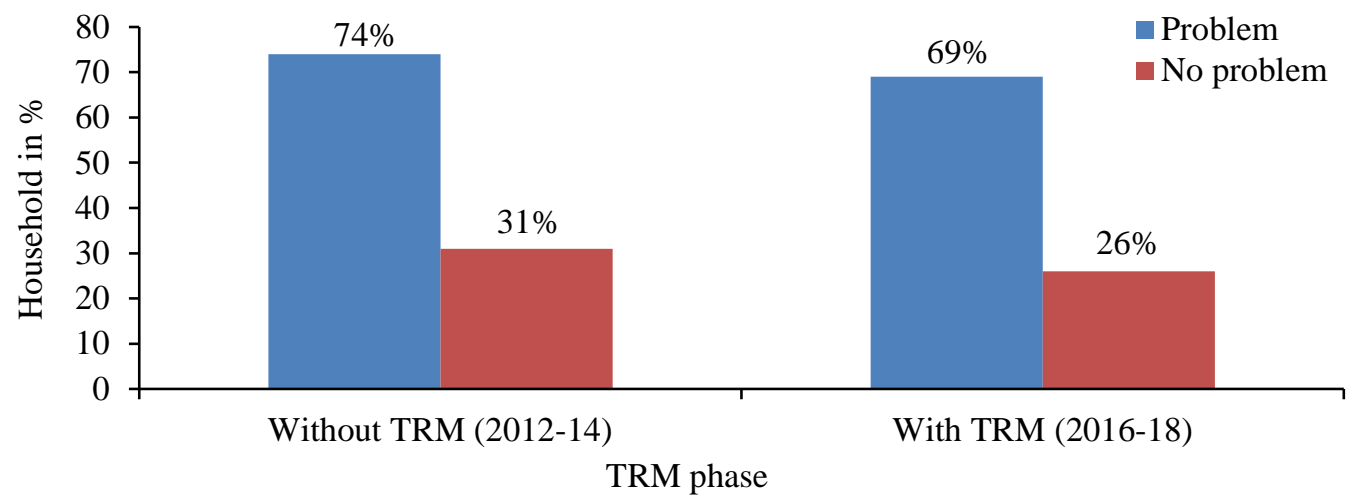

Figure 4. Drinking water problem

Cases of sanitation and diarrhea disease in different TRM periods

The waterlogged conditions can affect the environment by expanding water-borne diseases (like diarrhea) there is a negative relationship between sanitation and water-borne diseases which occur due to the low sanitation system. This study revealed that 62 cases from the total households suffered from diarrhea during with-TRM event. This number increased to 163 cases during with-TRM event as there is still a present waterlogged condition in the lower part of the beel. In waterlogging conditions, people suffered from sanitation problems for 180 days at (without-TRM) event and 90 days at (with-TRM).

\section{Compensation scenario}

The main reason for the uncertainty of this project was the complexity of compensation. Only the land owners got crop compensation. Poor farmers who were dependent on the Pakhimara beel were being deprived of it. The problem was the complication of the withdrawal. For this reason, many farmers were not interested in applying for withdrawals. This study found that only $54 \%$ of marginal farmers and $73 \%$ from other farmer received crop compensation (Table 5).

Table 5. Farmers receiving crop compensation from the government

\begin{tabular}{lc}
\hline \multicolumn{1}{c}{$\begin{array}{c}\text { Farmer } \\
\text { type }\end{array}$} & $\begin{array}{c}\text { Farmer get } \\
\text { compensation \% }\end{array}$ \\
\hline $\begin{array}{l}\text { Marginal farmer }(<100 \\
\text { decimal land) }\end{array}$ & $54 \%$ \\
$\begin{array}{l}\text { Another farmer }(>100 \\
\text { decimal land) }\end{array}$ & $73 \%$ \\
\hline
\end{tabular}

\section{Assessment of the changes in waterlogging and vegetation with settlement}

The study used six satellite images for premonsoon (April), monsoon (August) and postmonsoon (December) in 2014 and 2018 for TRM at Pakhimara beel, in terms of agricultural land, water body and the vegetation with settlement. TRM operation took place in the Pakhimara beel in 2015 and it was supposed to be completed in 2018. The results of the images are summarized in Table 6.

Table 6. Changes in waterlogging and vegetation with settlement at Pakhimara tidal basin

\begin{tabular}{lrrcccc}
\hline \multirow{2}{*}{ Land use (ha) } & \multicolumn{3}{c}{2014 (without-TRM) } & \multicolumn{3}{c}{2018 (with-TRM) } \\
\cline { 2 - 7 } & April & August & December & April & August & December \\
\hline Water body & 900 & 9,800 & 1,100 & 1,600 & 4,300 & 4,700 \\
Vegetation with settlement & 3,700 & 0 & 2,500 & 3,800 & 1,300 & 1,600 \\
Agricultural land & 5,200 & 0 & 6,200 & 4,400 & 4,200 & 3,500 \\
\hline
\end{tabular}


Table 6 and Figure 5 indicated that the agricultural land occupied 53\% (5,200 ha) of the total area during the pre-monsoon (April) period of without-TRM in 2014. Due to TRM operation, this value reduced to $44 \%$ (4,400 ha) during 2018. The water body held $100 \%(9,800 \mathrm{ha})$ and $11 \%(1,100 \mathrm{ha})$ of the total land in 2014 for monsoon and post-monsoon. The values dropped to $44 \%$ (4,300 ha) during monsoon in 2018 (with-TRM) but increased to $36 \%$ (4,700 ha) in post-monsoon in 2018 (with-TRM). During the monsoon period (with-TRM event)
5,500 ha land were respectively freed from waterlogging in 2018 as compared to 2014 (without-TRM). This reduction of waterlogging increased agricultural land and crop yields by 0 to 4,200 ha at monsoon in 2018 , compared to 2014. However, in the pre-monsoon period, 900 ha of land faced waterlogging in 2014 (without-TRM), which then increased to 1,600 ha during TRM event. Moreover, the vegetation with settlement was increased by 1,300 ha for monsoon in 2018 (with-TRM) as compared to 2014 (without-TRM).

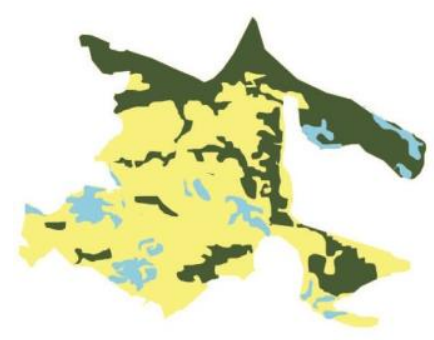

April 2014

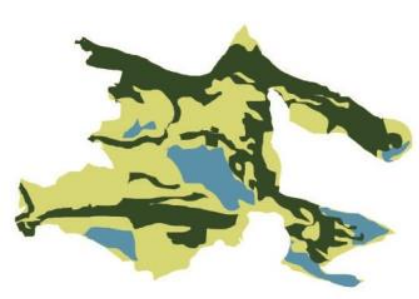

April 2018

Legend:

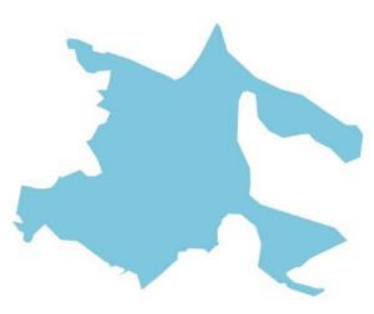

August 2014

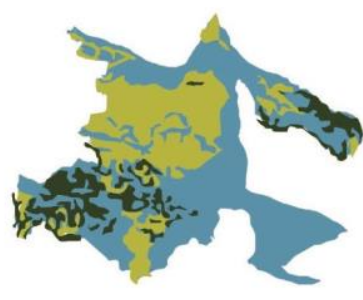

August 2018

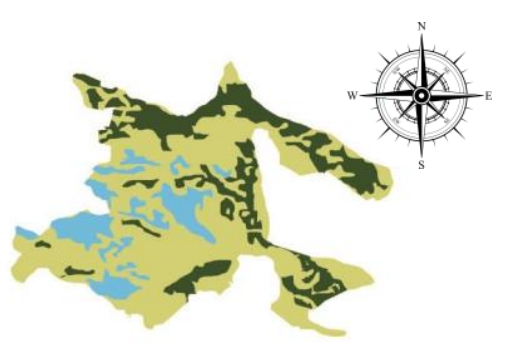

December 2014

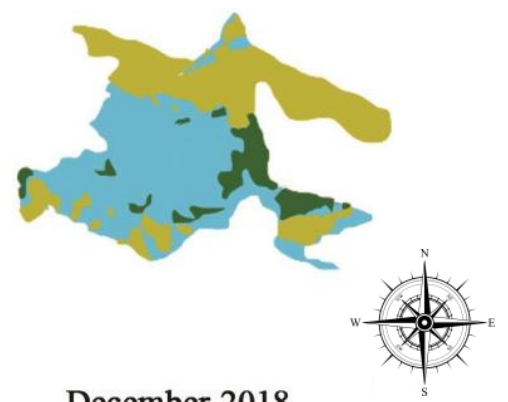

December 2018

Figure 5. The satellite images for pre-monsoon, monsoon and post-monsoon in 2014 and 2018 for TRM

\begin{abstract}
Assessment of the riverbank erosion, awareness and coordination, and rotation

This research assessed the opinions of key informants by applying a 5-grade Likert scale for these indicators in the tidal basin. The Likert scale is a five-point scale that is used to scaling the opinions of an expert in survey research. The level of respondents' satisfaction is presented in three conditions, including 'disagree' ( $1 \& 2)$, 'neutral' (3) and 'agree' (4 \& 5) (Saranya and Karthikeyan, 2015).
\end{abstract}

Table 7 demonstrates four important performances under riverbank erosion in the Pakhimara tidal basin. In terms of government authority/NGOs' efforts in resettling people if necessary and installing concrete blocked on the riverbank to protect from erosion, the maximum score of 5 and the minimum score of 1.6 were obtained. This indicator captures $54 \%$ satisfaction and earns 2.7 out of 5 point.

Table 8 presents five important performances under the awareness and coordination of 
community people in the Pakhimara tidal basin. The maximum score of 3.6 and the minimum score of 1.5 were yielded for people's willingness to be involved in TRM project and active role of CBOs (community-based organisations) and local NGOs regarding TRM project.

Table 7. Expert opinion regarding riverbank erosion

\begin{tabular}{lc}
\multicolumn{1}{c}{ Riverbank erosion } & $\begin{array}{c}\text { Score for satisfaction } \\
\text { (out of 5) }\end{array}$ \\
\hline GOs' efforts in raising the awareness of people living in the bank side & 1.8 \\
CBOS' efforts in raising the awareness of people living in the bank side & 2.7 \\
Building concrete blocks on the riverbank to protect from erosion & 1.6 \\
Government authority/NGOs' efforts in resettling people if necessary & 5.0 \\
\hline
\end{tabular}

Table 8. Expert opinion regarding awareness and coordination of TRM

\begin{tabular}{lc}
\multicolumn{1}{c}{ Awareness and coordination } & $\begin{array}{c}\text { Score for satisfaction } \\
\text { (out of 5) }\end{array}$ \\
\hline $\begin{array}{l}\text { People's willingness to be involved in TRM project (compensation, dam, } \\
\text { cut point, time fixation and area) }\end{array}$ & 3.6 \\
Active role of CBOs and local NGOs regarding TRM project & 1.5 \\
Coordination between GOs and CBOs for village protection dam & 2.8 \\
Coordination between GOs and CBOs for TRM project time fixation & 2.1 \\
Coordination between GOs and CBOs for compensation & 1.6 \\
\hline
\end{tabular}

Overall, 13 indicators were used to assess the impacts of TRM, five of which were positive, while the rest were negative, during the TRM implementation period in the tidal basin (Figure 6). From the assessment, TRM improved the waterlogging condition, which was a major burden for the local people. Sterrett (2011) concluded in his research that TRM has a positive influence on improving drainage capacity and removing water congestion. TRM also had a positive influence on lowering riverbank erosion, as well as improving sanitation and drinking water quality. These all parameters ensured good water governance. On the contrary, local dwellers were negatively impacted in terms of crop production due to the loss of land in the tidal basin. Rate of migration also increased due to the lack of employment opportunities. A total of $12 \%$ of the migration was estimated due to waterlogging problem (Chu, 2007). Ahmed (2008) and Adri (2009) identified that prolonged waterlogging leads to working males' migration to the cities for searching job by leaving their wives and children at home.

Overall, basin biodiversity changed due to shift in hydrological behavior. By assessing the key indicators, it can be recapitulated that TRM negatively affected the basin area, although it might be beneficial for catchment area.
The most essential advantages of TRM were sediment management (Khadim et al., 2013) and the removal of waterlogging from beel (Tutu, 2005; Paul et al., 2013; Jakarya et al., 2016), which could extend fisheries, agriculture, employment promoting better socio-economic condition. CEGIS (2003) and Paul et al. (2013) conducted socio-economic analysis in TRM implemented area to analyze the livelihood pattern of local people. They concluded that TRM improves to grow biodiversity by strengthening environment and finally, improving socio-economic conditions of the people living in the coastal area.

The overall scenario may be nullified by some complexities, like riverbank erosion, the reduction of agricultural land, and the loss of employment in the basin areas. De Die (2013) and Gain et al. (2017) stated that conflicts may be triggered due to the implementation of non-acceptance TRM. Therefore, TRM should be implemented by involving all level of stakeholders in the implementation area. Paul et al. (2013) and Gain et al. (2017) described in their study that riverbank erosion, disruption of road network, inundation of agricultural land and low rate of compensation to the land owners might be the potential causes for arising TRM complexity. The present study also discovered the same indicators negatively impacted the TRM basin areas. 


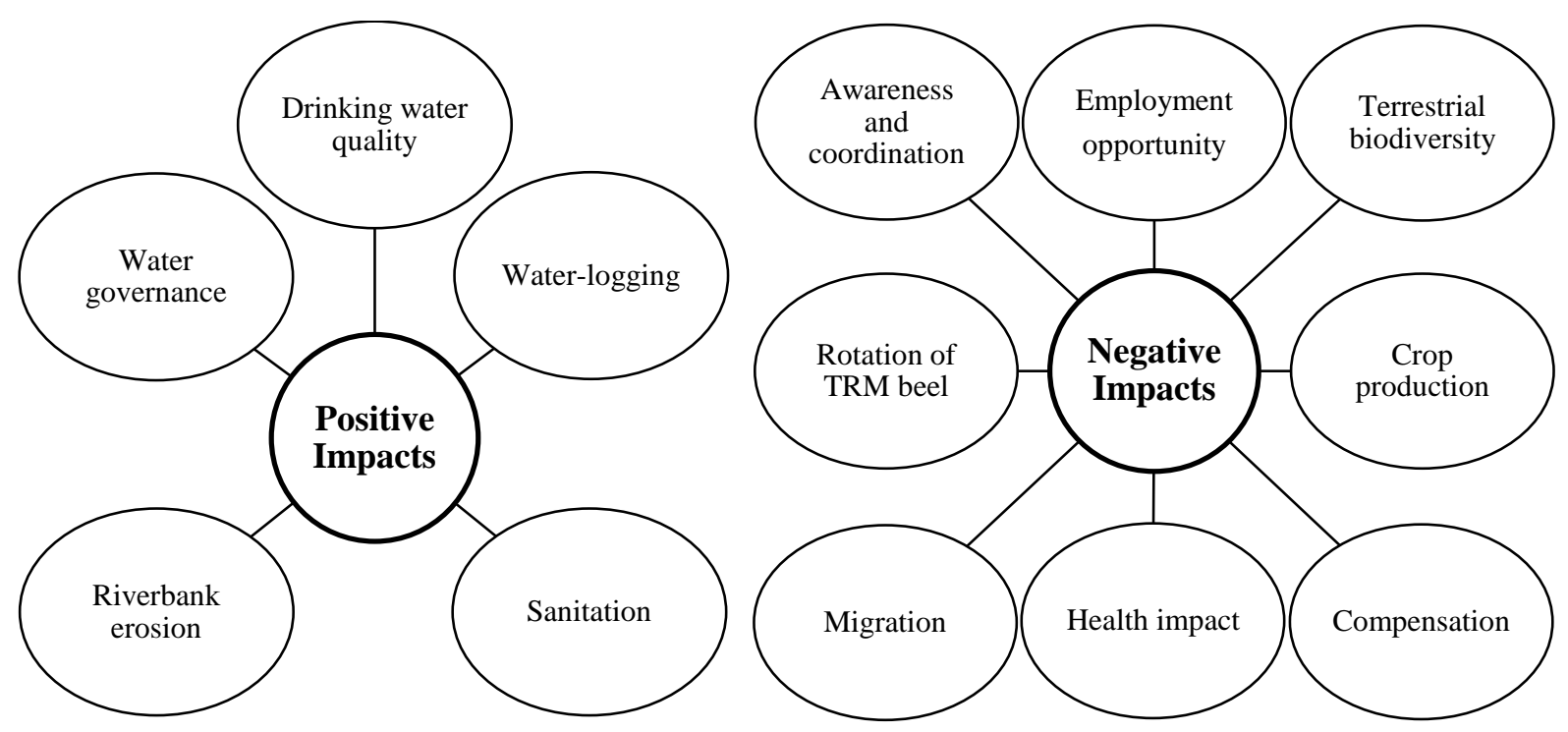

Figure 6. Positive and negative impacts of TRM

Bangladesh has set a long term protection strategy in the long run, called Bangladesh Delta Plan (BDP 2100) (GoB, 2014), in which TRM could be acknowledged as a problem solving factor for waterlogging (Saranya and Karthikeyan, 2015; van Staveren et al., 2017). However, a lot of conflicts and interests took place for implementing the project (Gain et al., 2017; Cornwall, 2018; Mutahara et al., 2018). Without healthy monitoring, nothing could make a success. Marginal farmers in the tidal basin were negatively impacted due to TRM. In the southwest Ganges-Brahmaputra delta, TRM could be operated in more than 35 beels (Nicholls et al., 2008; Amir, 2010). TRM has been implemented in 12 of 35 beels (Gain et al., 2017). In most of the cases, TRM could remove waterlogging but brought conflicts among the stakeholders (De Die, 2013). For a successful outcome, the compensation as well as economic benefits should be equally distributed and biodiversity and migration protection should be ensured. Bangladesh got the TRM concept from the Netherlands where successful economic and protection of biodiversity were observed for implementing TRM (Khan et al., 2014; van Staveren and van Tatenhove, 2016).

\section{CONCLUSIONS}

TRM is an important issue for the local people of Pakhimara beel area. The TRM project was approved for implementation in four years but the authority failed to complete TRM project in time (2018). This project produced both positive and negative impacts, with most indicators showing negative impacts. In Pakhimara beel, local people did not face the impact of waterlogging in their daily activities although the navigability of the river was deteriorating, and thus, TRM implementation was not their main demand. For ensuring sustainable TRM, proper compensation distribution should be ensured along with the creation of employment opportunities and settlement.

\section{ACKNOWLEDGEMENT}

The authors thank to all staff of Soil, Water and Environment Discipline of Khulna University, Bangladesh and the local people, as well as the stakeholders in the studied area.

\section{REFERENCES}

Adnan, M. S. G., Talchabhadel, R., Nakagawab, H., \& Hall, J. W. (2020). The potential of tidal river management for flood alleviation in South-western Bangladesh. Science of the Total Environment, 731, 138747. https:// doi.org/10.1016/j.scitotenv.2020.138747

Adri, N. (2009). Assessment of vulnerability of people in a waterlogged area of Bangladesh: a case study of Keshabpur Thana [Master thesis]. Dhaka, Bangladesh: Bangladesh University of Engineering and Technology (BUET). Retrieved from http:// lib.buet.ac.bd:8080/xm 
lui/handle/123456789/3071

Ahmed, A. U. (2008). Desakota phenomenon observed in Satkhira-Khulna-Jessore-Dhaka corridor in the Southwest Bangladesh. Part II F1 Case Study. Retrieved from http://www. nerc.ac.uk/research/funded/programmes/espa/ final-report-desakota-part2-f1

Amir, M. S. I. I. (2010). Socio-technical assessment of sediment management options in tidal basins in Southwestern Bangladesh [Master thesis]. Dhaka, Bangladesh: Department of Institute of Water and Flood Management (IWFM), Bangladesh University of Engineering \& Technology (BUET). Retrieved from http://lib.buet.ac.bd:8080/xml ui/handle/123456789/2663?show=full

Brammer, H. (2014). Bangladesh's dynamic coastal regions and sea-level rise. Climate Risk Management, 1, 51-62. https://doi.org/ 10.1016/j.crm.2013.10.001

CEGIS. (2003). Monitoring and integration of the environmental and socio-economic impacts of implementing the tidal river management option to solve the problem of drainage congestion in KJDRP area. Dhaka, Bangladesh: Center for Environmental and Geographic Information Services (CEGIS). Retrieved from https://scholar.google.co.id/ scholar?cites $=13530067783302588557 \&$ as_s $\mathrm{dt}=2005 \&$ sciodt $=0,5 \& \mathrm{hl}=\mathrm{id} \&$ authuser $=3$

Chu, H. (2007). Global warming gains foothold in Bangladesh: climate changes already causing heavier flooding. Retrieved from http://archive.boston.com/news/world/as ia/articles/2007/02/25/global_warming_gains _foothold_in_bangladesh/

Cornwall, W. (2018). Bending to the water's will. Science, 359(6379), 980-985. https:// doi.org/10.1126/science.359.6379.980

De Die, L. (2013). Tidal river management: temporary depoldering to mitigate drainage congestion in the Southwest Delta of Bangladesh [Master thesis]. Wageningen, Netherlands: Water Resources Management, International Land and Water Management, Water Resources Management, Wageningen University. Retrieved from https://library.wur. nl/WebQuery/titel/2034200

Dewan, C., Mukherji, A., \& Buisson, M. C.
(2015). Evolution of water management in coastal Bangladesh: from temporary earthen embankments to depoliticized communitymanaged polders. Water International, 40 (3), 401-416. https://doi.org/10.1080/025080 60.2015.1025196

Gain, A. K., Benson, D., Rahman, R., Datta, D. K., \& Rouillard, J. J. (2017). Tidal river management in the south west GangesBrahmaputra delta in Bangladesh: moving towards a transdisciplinary approach. Environmental Science \& Policy, 75, 111-120. https://doi.org/10.1016/j.envsci.2017.05.020

Gain, A. K., Ashik-Ur-Rahman, M., \& Benson, D. (2019a). Exploring institutional structures for tidal river management in the GangesBrahmaputra Delta in Bangladesh. DIE ERDE-Journal of the Geographical Society of Berlin, 150(3), 184-195. https://doi.org/ 10.12854/erde-2019-434

Gain, A. K., Ashik-Ur-Rahman, M., \& Vafeidis, A. (2019b). Exploring human-nature interaction on the coastal floodplain in the Ganges-Brahmaputra delta through the lens of Ostrom's social-ecological systems framework. Environmental Research Communications, 1, 051003. https://doi.org/ $10.1088 / 2515-7620 / \mathrm{ab} 2407$

GoB. (2014). Inception report. Bangladesh Delta plan 2100 formulation project. Dhaka: General Economics Division (GED), Planning Commission, Government of the People's Republic of Bangladesh.

Hossain, M., \& Salam, M. T. B. (2019). Changes in soil physico-chemical properties and fertility status of long-term cultivated soils in Southwestern Bangladesh. Malaysian Journal of Soil Science, 23, 31-41. Retrieved from http://www.msss.com.my/mjss/Full\%20 Text/vol23/V23_03.pdf

Hussain, N., Islam, M. H., \& Firdaus, F. (2018). Impact of tidal river management (TRM) for water logging: a geospatial case study on coastal zone of Bangladesh. Journal of Geoscience and Environment Protection, 6(12), 122-132. https://doi.org/10.4236/gep. 2018.612009

Islam, Z. (2014). Effects of water logging on people's life and livelihoods in the Southwest 
Region of Bangladesh : A case study on Tala Upazila, Satkhira. Dhaka, Bangladesh: Department of Geography and Environment, Faculty of Earth and Environmental Sciences, University of Dhaka. Retrieved from https:// www.researchgate.net/publication/304599547 _Effects_of_Water_logging_on_people's_life _and_livelihoods_in_the_south_west_region_ of_Bangladesh_A_case_study_on_Tala_Upaz ila_Satkhira

Jakarya, M., Sikder, M. T., \& Yousuf, A. I. (2016). Review of an integrated strategy of climate change adaptation using tidal river management. Journal of Health and Environmental Research, 2(1), 1-4. https:// doi.org/10.11648/j.jher.20160201.11

Khadim, F. K., Kar, K. K., Halder, P. K., Rahman, M. A., \& Morshed, A. K. M. M. (2013). Integrated water resources management (IWRM) impacts in South West Coastal Zone of Bangladesh and fact-finding on tidal river management (TRM). Journal of Water Resource and Protection, 5(10), 953-961. https://doi.org/10.4236/jwarp.2013.510098

Khan, H., Marwat, K. B., Khan, M. A., \& Hashim, S. (2014). Herbicidal control of parthenium weed in maize. Pakistan Journal of Botany, 46(2), 497-504. Retrieved from https://www. pakbs.org/pjbot/PDFs/46(2)/13.pdf

Khatun, M., Shuvo, M. A. R., Salam, M. T. B., \& Rahman, S. M. H. (2019). Effect of organic amendments on soil salinity and the growth of maize (Zea mays L.). Plant Science Today, 6(2), 106-111. https://doi.org/10.14719/pst. 2019.6.2.491

Kibria, Z. (2011). Tidal river management: climate change adaptation and community based river basin management in Southwest Coastal Region of Bangladesh. Retrieved from https://www.ctc-n.org/resources/tidal-rivermanagement-climate-change-adaptation-andcommunity-based-river-basin

Kothari, C. R. (2004). Research methodology: methods and techniques (2nd ed). Delhi, India: New Age International. Retrieved from https:// scholar.google.co.id/scholar?cites $=16539857$ $61729053979 \&$ as_sdt $=2005 \&$ sciodt $=0,5 \& \mathrm{hl}=$ id\&authuser $=3$

Masud, M. M. A., \& Azad, A. K. (2018). The role of tidal river management for sustainable agriculture. Proceedings of 2 nd International Conference on Sustainable Development, 189-200. Retrieved from https://www. researchgate.net/publication/330351845_The _Role_of_Tidal_River_Management_for_Sus tainable_Agriculture_pp_189-200

Masud, M. M. A., Gain, A. K., \& Azad, A. K. (2020). Tidal river management for sustainable agriculture in the GangesBrahmaputra delta: Implication for land use policy. Land Use Policy, 92, 104443. https://doi.org/10.1016/j.landusepol.2019.104 443

Masud, M. M. A., Moni, N. N., Azad, A. K., \& Swarnokar, S. C. (2018). The impact of tidal river management on livestock in the GangesBrahmaputra Basin. Journal of Dairy \& Veterinary Sciences, 6(5), 555696. https://doi. org/10.19080/JDVS.2018.06.555696

Masud, M. M.A., Moni, N. N., Azadi, H., \& Van Passel, S. (2018). Sustainability impacts of tidal river management: towards a conceptual framework. Ecological Indicator, 85, 451467. https://doi.org/10.1016/j.ecolind.2017.10 .022

Mutahara, M., Warner, J. F., Wals, A. E. J., Khan, M. S. A., \& Wester, P. (2018). Social learning for adaptive delta management: tidal river management in the Bangladesh Delta. International Journal of Water Resources Development, 34(6), 923-943. https://doi.org/ 10.1080/07900627.2017.1326880

Nicholls, R. J., Wong, P. P., Burkett, V., Woodroffe, C. D., \& Hay, J. (2008). Climate change and coastal vulnerability assessment: scenarios for integrated assessment. Sustainability Science, 3(1), 89-102. https:// doi.org/10.1007/s11625-008-0050-4

Paul, A., Nath, B., \& Abbas, M. R. (2013). Tidal river management (TRM) and its implication in disaster management: a geospatial study on Hari-Teka river basin, Jessore, Bangladesh. International Journal of Geomatics and Geosciences, 4(1), 125-135. Retrieved from https://www.cabdirect.org/cabdirect/abstract/2 0133380387

Roy, K., Gain, A. K., Mallick, B., \& Vogt, J. (2017). Social, hydro-ecological and climatic 
change in the southwest coastal region of Bangladesh. Regional Environmental Change, 17, 1895-1906. https://doi.org/10.1007/s101 13-017-1158-9

Salam, M. T. B, Karmakar, B., Hossain, S. M. T., Robin, M. H., Mariam, M. Z., \& Hossain, M. (2019). Agronomic performance of modern rice varieties in South-west Bangladesh. Plant Science Today, 6(4), 528-532. https://doi.org/ 10.14719/pst.2019.6.4.632

Saranya, B., \& Karthikeyan, G. B. (2015). A study on preferences and level of satisfaction towards post office savings schemes (with special reference to Coimbatore City). International Journal of Management, 6(1), 771-775. Retrieved from https://iaeme.com/ MasterAdmin/Journal_uploads/IJM/VOLUM E_6_ISSUE_1/10120150601081.pdf

Sarwar, G. M., \& Khan, M. H. (2007). Sea level rise. A threat to the coast of Bangladesh. Internationaels Asienforum, 38(3-4), 375397. https://doi.org/10.11588/iaf.2007.38.329

Seijger, C., Datta, D. K., Douvena, W., van Halsema, G., \& Khan, M. F. (2019). Rethinking sediments, tidal rivers and delta livelihoods: tidal river management as a strategic innovation in Bangladesh. Water Policy, 21(1), 108-126. https://doi.org/ 10.2166/wp.2018.212

Shampa, \& Pramanik, M. I. M. (2012). Tidal River Management (TRM) for selected Coastal area of Bangladesh to mitigate drainage congestion. International Journal of Scientific \& Technology Research, 1(5), 1-6. Retrieved from https://citeseerx.ist.psu.edu/ viewdoc/download?doi=10.1.1.298.2254\&rep
$=$ rep $1 \&$ type $=$ pdf

SRDI. (2007). Soil resource development institute. In Thana Nirdeshika Guide. Dhaka: Ministry of Agriculture, Bangladesh.

Sterrett, C. (2011). Review of climate change adaptation practices in South Asia. Retrieved from https://www-cdn.oxfam.org/s3fs-public/ file_attachments/rr-climate-change-adaptation -south-asia-161111-en_3.pdf

Tutu, A. A. (2005). River management in Bangladesh: a people's initiative to solve waterlogging. Participatory Learning and Action, 51, 117-123. Retrieved from https:// pubs.iied.org/sites/default/files/pdfs/migrate/ G02131.pdf

Uttaran, CEGIS (Center for Environmental and Geographic Information Services, \& IMW (Institute of Water Modelling). (2013). People's plan of action for management of rivers in South-West Coastal Region of Bangladesh. Dhaka, Bangladesh: Uttaran. Retrieved from http://www.uttaran.net/publi cations/peopleplanofaction.pdf

van Staveren, M. F., \& van Tatenhove, J. P. M. (2016). Hydraulic engineering in the socialecological delta: understanding the interplay between social, ecological, and technological systems in the Dutch delta by means of "delta trajectories." Ecological Society, 21(1), 8. https://doi.org/10.5751/ES-08168-210108

van Staveren, M. F., Warner, J. F., \& Khan, S. A. (2017). Bringing in the tides. From closing down to opening up delta polders via Tidal River Management in the southwest delta of Bangladesh. Water Policy, 19(1), 147-164. https://doi.org/10.2166/wp.2016.029 